\title{
MINERAL NITROGEN CONTENT IN SOILS DEPENDING ON LAND USE AND AGRONOMIC CATEGORY
}

\author{
WATROS, A. ${ }^{1}$ - TKACZYK, P. ${ }^{2}$ - LIPIŃSKA, H. ${ }^{3}$ - LIPIŃSKI, W. ${ }^{4}$ - KRZYSZCZAK, J. ${ }^{5 *}$ \\ BARANOWSKI, P. ${ }^{5}-$ BRODOWSKA, M. S. ${ }^{2}$ \\ ${ }^{1}$ New Chemical Synthesis Institute \\ Al. Tysiąclecia Państwa Polskiego 13 A, 24-110 Puławy, Poland \\ ${ }^{2}$ Department of Agricultural and Environmental Chemistry, University of Life Sciences in \\ Lublin, ul. Akademicka 15, 20-950 Lublin, Poland \\ ${ }^{3}$ Department of Grassland Science and Landscaping, University of Life Sciences in Lublin \\ ul. Akademicka 15, 20-950 Lublin, Poland \\ ${ }^{4}$ State School of Higher Education in Chetm, ul. Pocztowa 54, 22-100 Chetm, Poland \\ ${ }^{5}$ Institute of Agrophysics Polish Academy of Sciences \\ ul. Doświadczalna 4, 20-290 Lublin, Poland \\ (phone: +48 (81) 74450 61; fax: +48 (81) 74450 67) \\ *Corresponding author \\ e-mail: jkrzyszczak@ipan.lublin.pl; phone: (81) 74450 61; fax: (81) 7445067
}

(Received $9^{\text {th }}$ Jan 2019; accepted $6^{\text {th }}$ Mar 2019)

\begin{abstract}
Evaluation of mineral nitrogen content $\left(\mathrm{N}_{\min }\right)$ was performed for the $60-90 \mathrm{~cm}$ layer of grassland soils relative to other selected agricultural fodder crops. Soil samples were collected two times per year, in spring and autumn, over the period 2010-2012 from fixed locations scattered across whole Poland territory. Additionally, particle-size distribution was assessed in the tested soil samples, which allowed to assign soil agronomic categories to them and assess the relationship between $\mathrm{N}_{\min }$ content and assigned categories. Regardless of sampling date and land use, agronomic category had a significant effect on $\mathrm{N}_{\min }$ content. Generally the relationships between the percentage of particles with dimensions below $0.02 \mathrm{~mm}$ and $\mathrm{N}_{\min }$ content were characterized by a negative correlations, but in maize crops they were found to be positively correlated. Based on the obtained correlations, linear regression equations were developed. Calculated relations were less pronounced in spring, before fertilization, than in the autumn, after harvest. These equations can be very important from the practical point of view, as they may be used by farmer to plan a rational and sustainable fertilization based on forecasting of losses of mineral nitrogen content in the soil depending on the percentage of fine particles (agronomic category) of cultivated soil.
\end{abstract}

Keywords: mineral soils, organic soils, maize, mixed cereals, regression equations

\section{Introduction}

Nitrogen is one of the most important macronutrients, playing crucial role in crop growth process. The management of mineral nitrogen to ensure optimal level for plants is strongly dependent on physico-chemical properties of cultivated soil, such as particlesize distribution, bulk density, porosity or $\mathrm{pH}$, crop management practices, as well as climatic conditions, which not only are a subject of constant changes, but also experienced a sudden shift related to climate change resulting in temperature increase (Swanson and Tsonis, 2009) and variation in precipitation structure. Increasing global food demand and gradually diminishing arable land area put new challenges for crop 
production, which can be fulfilled by precision agriculture and sustainable soil management. For example, in Poland arable land as a share of land area fell gradually from $45.6 \%$ in 2000 to $35.6 \%$ in 2015 (The World Bank, 2015), but yields per hectare are increasing, which is related to the intensification of plant production. Usually it involves the use of higher doses of fertilizers, what results in the stronger impact of agriculture on the environment, as about 40 to $70 \%$ of nitrogen applied as normal fertilizer is either chemically bound in the soil and becomes unavailable to plants or is lost to the environment due to leaching (Jarosiewicz and Tomaszewska, 2003). In terms of sustainable agriculture, intensification should be strongly connected with optimization of efficiency of fertilizers use by modifications leading to graduation of their release time and biochemical activity. Also, the application of fertilizers for specific location should take into account soil bio-physico-chemical status, expressed through particle size distribution, mineralogical composition, soil $\mathrm{pH}$, water retention properties and hydraulic conductivity, organic matter content or soil microbial community composition, activity of which can depend not only on $\mathrm{N}$ fertilization (GleńKarolczyk et al., 2018; Walkiewicz et al., 2018), but also on contamination (Walkiewicz et al., 2016; Wnuk et al., 2017). Poland is a region characterized by a significant diversification of soils and thus, the agricultural production conditions. Therefore, regular monitoring of soil properties and analysis of their relations with macro and micronutrients status (Tkaczyk et al., 2017; 2018a; 2018b) that is taking into account the diversity of soils is necessary for appropriate distribution and application of NPK fertilizers and their sustainable management (Tunbare et al., 2005; Watros et al., 2018). This can be done by precise prediction of soil properties variations in space and time using physical-mathematical modelling (Lamorski et al., 2013), which consider spatiotemporal variations of soil and climate conditions. To consider crop production in the conditions of a changing climate, various approaches can be applied. They capture projections of future climate from climatic models, which take into account various climate change scenarios, by either modification of amplitudes of partial density functions of measured time series to be in accordance with predicted climate change (Pirttioja et al., 2015; Fronzek et al., 2018) and consider adaptation measures (RuizRamos et al., 2018; Rodríguez et al., 2019), or take into account various statistical models (Murat et al., 2018) to forecast hourly or daily courses of future time series. It was shown that modifications of the weather time series structure (either by changing amplitudes or by an spatio-temporal aggregation) interfere with their inherent properties, such as long distance power-law correlations (Baranowski et al., 2015; Hoffmann et al., 2017; Krzyszczak et al., 2017a; 2017b; Krzyszczak et al., 2018) and therefore should be done with appropriate caution, as it may highly influence the results of modelling.

The most general form of presenting soil properties and analyzing their impact on crop production is the use of agronomic category. The studies on impact of agronomic category on mineral nitrogen in soil makes it possible for farmers to easily evaluate fertilization needs for a specific soil type. Up to this moment there are not many studies regarding the relation agronomic category on soil mineral nitrogen performed in large scale covering whole country area, which consider sampling date and land use. For example, it was already shown that, in general, soil mineral nitrogen content is affected by soil agronomic category (Paz and Ramos, 2004). Differences in soil mineral nitrogen content in spring and autumn sampling dates, as well as the assessment of percentage of nitrate and ammonium nitrogen in mineral nitrogen content were assessed by Fotyma 
and Pietruch (2000) and Pietrzak (2014). Fotyma and Pietruch (2000) showed that in the 0-60 cm layer, the greatest variations in this respect were found in very light and light soils, whereas in the $60-90 \mathrm{~cm}$ layer heavy soils exhibited the largest differences. In medium and heavy soils, the percentage of ammonium nitrogen is about $30 \%$ of the total amount of mineral nitrogen, while in light soils this percentage is substantially higher, standing at $50 \%$. It can be explained by greater denitrification intensity in heavy soils (Mosier et al., 2002). Pietrzak (2014) stated that in the topsoil $(0-30 \mathrm{~cm})$ the highest content of mineral nitrogen are found in meadow soils with high permeability, i.e. light and very light soils, and that the amount of mineral nitrogen in meadow soils generally increases during growing season and decreases in the off-season.

Mineral nitrogen located in the $0-30 \mathrm{~cm}$ layer can migrate to deeper layers of the soil profile due to leaching (Powlson, 1988; Coyne and Frye, 2005). In the Soon et al. (2001) opinion, nitrogen losses in agriculture caused by nitrogen leaching are of significant importance for economic, production and environmental reasons. A direct consequence of mineral nitrogen leaching is pollution of ground and surface waters (Fotyma et al., 2010). In Poland monitoring of soil mineral nitrogen has been conducted for many years (Fotyma and Pietruch, 2000; Regulation, 2002; Jadczyszyn et al., 2010; Pietrzak, 2014). Based on this monitoring, the impact of soil $\mathrm{N}_{\min }$ content on water quality can be predicted. This study attempted to identify factors determining nitrogen content in the $60-90 \mathrm{~cm}$ soil layer from which nitrogen can migrate to waters. As soil mineral nitrogen content is expected to be highly varied in time (Yu et al., 2003), with higher content during the spring and lower at the turn of August and September, which is a result of changes in the intensity of nitrification and enhanced nitrogen uptake by plants (Łoginow et al., 1987), therefore the analysis was carried out for two sampling dates - spring and autumn.

The study hypothesis is that, depending on selected soil properties, land use and sampling dates, significant differences exist in the content of mineral nitrogen in the soil layer beneath $60 \mathrm{~cm}$, which is beyond the reach of the main root mass of crop plants in grassland soils (Mezhunts et al., 2005; Bonin et al., 2013) and in arable soils (Fan et al., 2016). The aim of this study was to evaluate mineral nitrogen content in grassland soils relative to other selected agricultural fodder crops in $60-90 \mathrm{~cm}$ layer depending on soil agronomic category.

\section{Material and methods}

\section{Sampling sites}

The results of environmental investigations conducted by the Regional Chemical and Agricultural Stations in agricultural farms across Poland over the period 2010-2012 were used to evaluate soil mineral nitrogen content for Polish soils under different land uses. The number of analyzed soil samples with the specified land use is presented in Table 1. Soil sampling sites, scattered over whole Poland territory, were identified by their geographical coordinates using GPS Pathfinder ProXT by Trimble (Westminster, CO 80021, USA, www.trimble.com) and were fixed for the entire study period. Locations of soil sampling points are presented in Fig. 1.

Soil samples were collected twice a year, in spring and autumn dates, from fields with a total area of not more than 4 ha. Soil sampling in spring were conducted in the period from February to April (before applying fertilizers), whereas in autumn in the period from September to October (after harvesting). Sampling done for 3 consecutive 
years diverse in terms of meteorological conditions (Tab. 2), with 2010 being cold and wet, 2011 - very warn and dry and 2012 - varm and moderate (Statistical yearbook, $2011 ; 2012 ; 2013)$, two times per year, allow to average out the influence of year-byyear variations of these conditions and reveal more the influence of agronomic categories on $\mathrm{N}$ content. Each sample, weighing about $200 \mathrm{~g}$, consisted of 15-20 primary soil samples collected from $60-90 \mathrm{~cm}$ layer using Egner stick from an area no larger than $100 \mathrm{~m}^{2}$.

For each site selected, if the same crop was grown in successive years of the study, the average value for the respective period was calculated. In the case of sites located in grasslands, the same land use was continued over the entire study period and the average $\mathrm{N}_{\min }$ content for the period 2010-2012 was considered.

Table 1. Number of analyzed soil samples taken from the 60-90 cm soil layer in grasslands on mineral soils, maize and mixed cereal (mostly oat and barley) crops

\begin{tabular}{c|c|c}
\hline \multicolumn{2}{c|}{ Crop type/land use } & Number of samples \\
\hline \multirow{4}{*}{ Grasslands (on mineral soils) } & Total & 859 \\
\cline { 2 - 3 } & Meadows & 521 \\
\cline { 2 - 3 } & Pastures & 160 \\
\cline { 2 - 3 } & Hay and pasture & 84 \\
\hline \multicolumn{2}{c}{ Maize } & Alternate \\
\hline
\end{tabular}
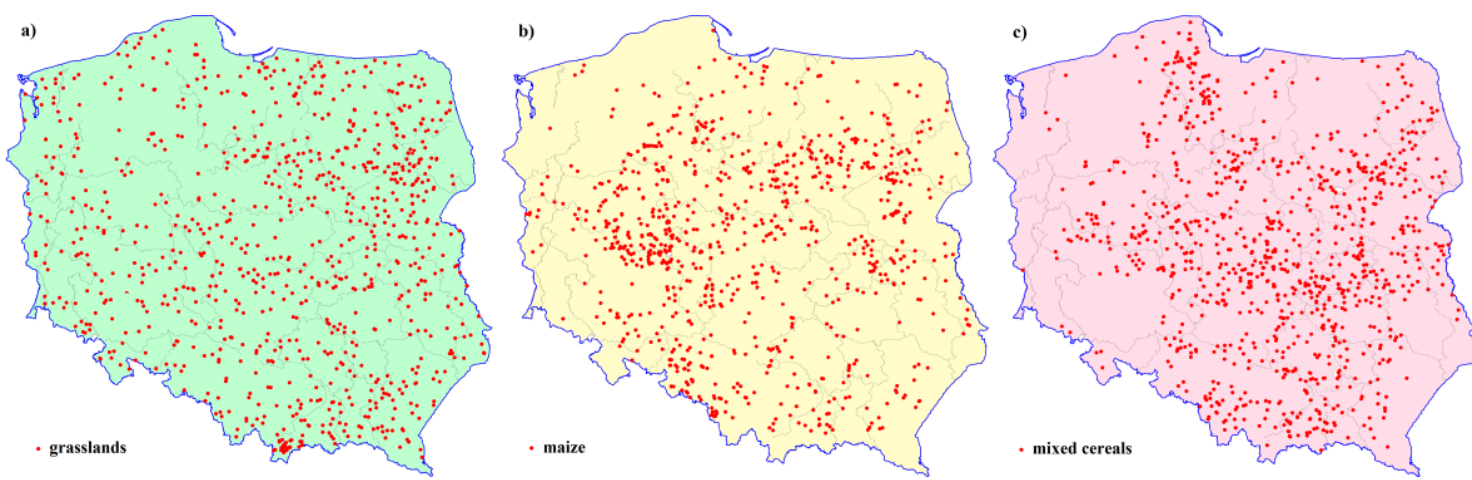

Figure 1. Location of soil sampling points from a) grasslands, b) maize and c) mixed cereals

Table 2. Basic meteorological conditions (on average) of the experimental years

\begin{tabular}{c|c|c|c}
\hline \multirow{2}{*}{ Meteorological parameter } & \multicolumn{3}{|c}{ Year } \\
\cline { 2 - 4 } & $\mathbf{2 0 1 0}$ & $\mathbf{2 0 1 1}$ & $\mathbf{2 0 1 2}$ \\
\hline Temperature $\left[{ }^{\circ} \mathrm{C}\right]$ & 7.1 & 8.5 & 8.1 \\
\hline Maximum temperature $\left[{ }^{\circ} \mathrm{C}\right]$ & 36.6 & 34.3 & 36.5 \\
\hline Minimum temperature $\left[{ }^{\circ} \mathrm{C}\right]$ & -29.0 & -25.1 & -29.9 \\
\hline Precipitation $[\mathrm{mm}]$ & 869.3 & 598.3 & 643.1 \\
\hline 1 day maximum precipitation $[\mathrm{mm}]$ & 186.2 & 140.5 & 66.2 \\
\hline Wind speed $[\mathrm{m} / \mathrm{s}]$ & 3.34 & 3.43 & 1850.9 \\
\hline Sunshine hours $[\mathrm{h}]$ & 1706.7 & 1973.7 & \\
\hline
\end{tabular}




\section{Soil samples analysis}

Collected samples were delivered to the respective laboratory in tightly sealed containers and kept at a temperature of $-18^{\circ} \mathrm{C}$ until an analysis of mineral nitrogen was performed. The soil samples with natural moisture content (after defrosting) were subjected to extraction with a $1 \%$ potassium sulfate solution at a ratio of $1: 10$. In the extracts obtained, nitrate and ammonium nitrogen content was determined spectrophotometrically using a Skalar San Plus System auto-analyzer (in accordance with the PN-R-04028:1997 norm, which is slightly modified, but equivalent to International Standard ISO 14256). Mineral nitrogen content (a sum of nitrate and ammonium nitrogen) was expressed in $\mathrm{mg} \cdot \mathrm{kg}^{-1}$ of dry matter of the soil sample (DM). Determination of dry matter was made using the gravimetric method after drying at $105^{\circ} \mathrm{C}$ (according to PN-ISO 11465:1999). In the air-dried samples, particle size distribution was determined using the laser diffraction method. As the extraction of nitrate and ammonium is carried out in a sample with natural moisture content, therefore obtained results were recalculated to the dry matter content using the empirical coefficient suitable for the soil of specific granulometric composition. Based on the content of particles with a diameter of $<0.02 \mathrm{~mm}$, one of four soil agronomic categories has been assigned to each soil sample (IUNG, 1990): very light soils $(<10 \%$ of fine particles), light soils (11-20\%), medium soils (21-35\%), and heavy soils (>35\% of fine particles).

\section{Statistical analysis}

To assess the relationship between soil agronomic category and content of mineral nitrogen in layer beyond the reach of roots of crop plants, $N_{\min }$ content in the $60-90 \mathrm{~cm}$ soil layer beneath ground surface in grasslands, as well as in soils under maize and mixed cereals was calculated as an annual average. Separately, averages were calculated for the spring and autumn sampling dates, depending on the assigned agronomic category and land use. Beside average values, standard deviations (SD) of mineral nitrogen content were calculated and presented on the figures. The relationships between $\mathrm{N}_{\min }$ content and agronomic category were characterized by Pearson's correlation coefficients and assessed statistically using the one-way non-orthogonal analysis of variance classification with Tukey confidence intervals $(p=0.05)$. Additionally, simple regression analysis performed in SAS v. 9.1 software was carried out to obtain linear equations describing the relationship between the soil agronomic category and the $\mathrm{N}_{\min }$ content in the $60-90 \mathrm{~cm}$ soil layer for varying land use. The goodness of fit of linear regression was evaluated using determination coefficients $\left(\mathrm{R}^{2}\right)$.

\section{Results and discussion}

The analyses show that indeed mineral nitrogen content in in the $60-90 \mathrm{~cm}$ soil layer depends on agronomic category (Fig. 2). The highest mineral nitrogen content was observed in light soils, whereas a slightly lower one in very light soils. This trend persisted both in spring and in autumn, except for very light soils for which a higher content of this form of nitrogen was noted in spring than in autumn (Fig. 3). The effect of seasonality on nitrogen mineralization in soils of peatland ecosystems is discussed by Pawluczuk and Gotkiewicz (2003). They showed much higher amounts of soil $\mathrm{N}_{\min }$ in spring than in summer and autumn. In their opinion, the reason for this is that in muck 
and peat soils enhanced mineralization occurs also in winter and the quantities of nitrogen unused by plants (because of the non-growing period) are lost. Also, Arbačiauskas et al. (2014) obtained similar tendencies for the $60-90 \mathrm{~cm}$ soil layer of Lithuanian agricultural lands, irrespective of soil texture or nitrogen fertilisation rate.

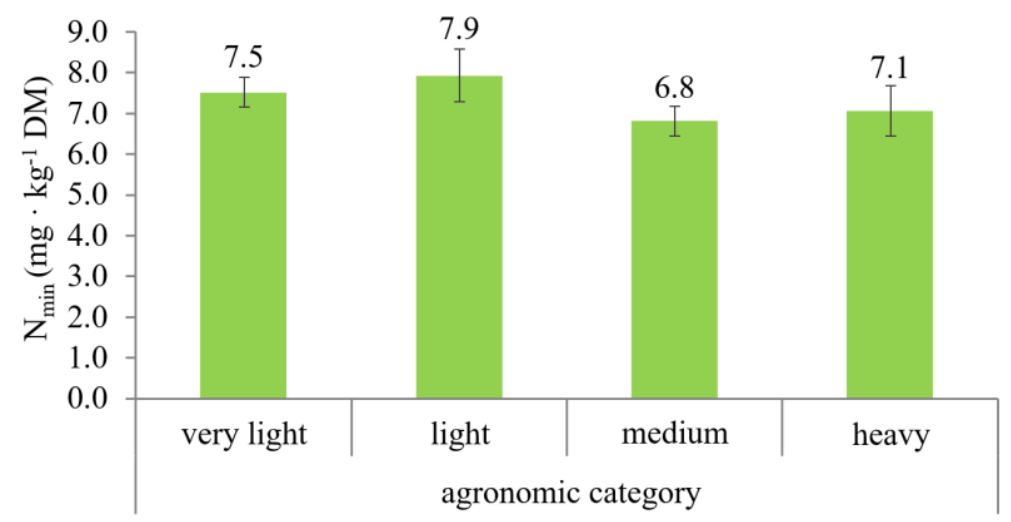

Figure 2. Average mineral nitrogen $N_{\min }$ content in the $60-90 \mathrm{~cm}$ soil layer with its standard deviation depending on soil agronomic category. DM stands for dry matter of the soil sample

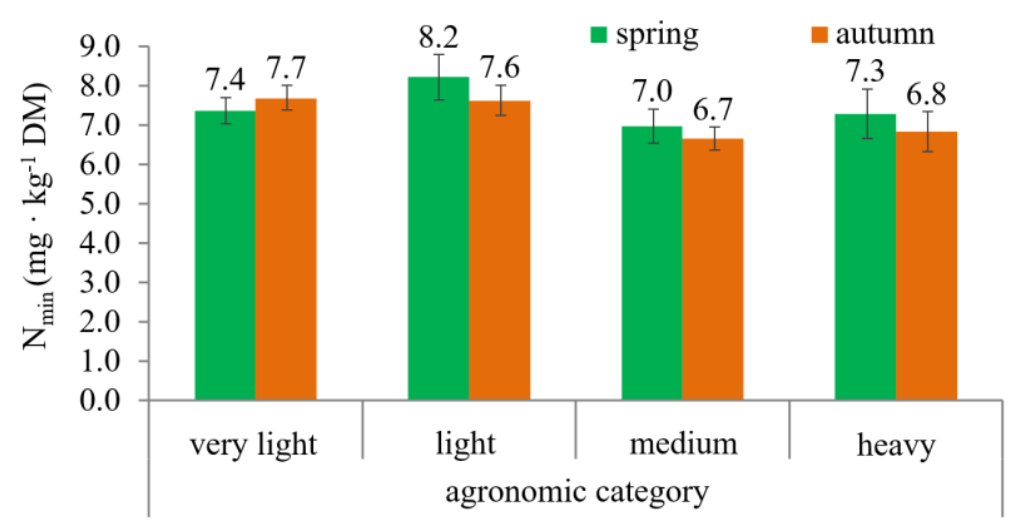

Figure 3. Average mineral nitrogen $N_{\min }$ content in the $60-90 \mathrm{~cm}$ layer of mineral soil with its standard deviation depending on agronomic category and soil sampling date. DM stands for dry matter of the soil sample

Higher mineral nitrogen contents in the 60-90 cm layer of very light and light soils relative to medium or heavy soils were also found in soil material taken from grassland soils and soils under mixed cereals. On the other hand, this relationship was opposite in the investigated layer in soils under maize because the highest $\mathrm{N}_{\min }$ content was found in heavy soils (Fig. 4). A much higher $\mathrm{N}_{\min }$ content in heavy soils relative to light soils was also found by Fotyma and Pietruch (2000). It was also shown that grassland soils accumulate less mineral nitrogen in the $60-90 \mathrm{~cm}$ layer than soils under mixed cereals or, which was even more evident, maize. Strong dependence of runoff and dissolved mineral nitrogen losses, and therefore differentiation of $\mathrm{N}_{\min }$ content in the deeper soil layers, on vegetation cover was noticed by García-Díaz et al. (2017) for vineyards. Also De Notaris et al. (2017) showed that N leaching is influenced by vegetation cover, with spring wheat and potatoes being the two crops with highest $\mathrm{N}$ leaching. 


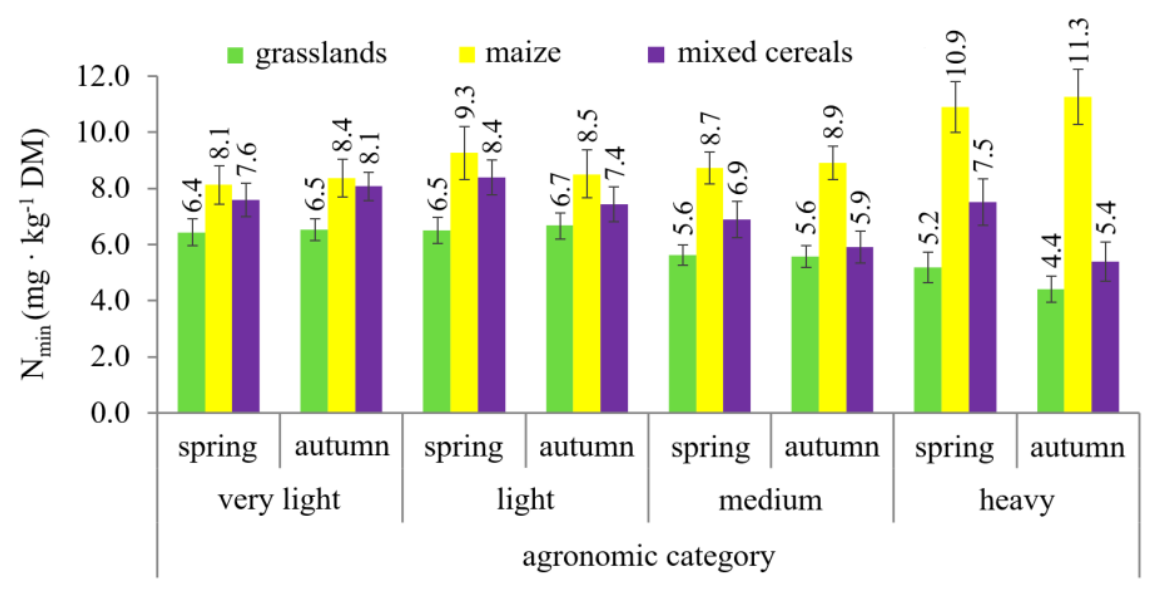

Figure 4. Average mineral nitrogen $N_{\min }$ content in the $60-90 \mathrm{~cm}$ layer of grassland soils and soils under maize and mixed cereals with its standard deviation depending on agronomic category and sampling date. DM stands for dry matter of the soil sample

Considering in turn mineral nitrogen content under different agronomic categories of grassland soils depending on land use, it was found that in most cases the highest content of this form of nitrogen at a depth of 60-90 cm was found in meadows (Fig. 5). The $\mathrm{N}_{\min }$ contents in pasture grasslands as well as in hay and pastures grasslands were at a similar level, whereas the lowest amount of nitrogen was detected in alternate grasslands, which was particularly visible in heavy soils. Under the specific soil agronomic categories, greater differences in mineral nitrogen content between particular grassland uses were noted in autumn than in spring. Pawluczuk and Szymczyk (2008) obtained similar results. They found a lower mineral nitrogen content in muck and peat soils in extensively used meadows compared to this content in muck and peat soils in pastures. In the case of extensive grassland use, they found a higher nitrate content in groundwater under meadows than under pastures. These authors substantiate this fact by greater phytosorption of nitrogen by pasture vegetation and a low groundwater level. Above factors adversely affect the movement of the nitrate form of nitrogen deeper into the soil profile.

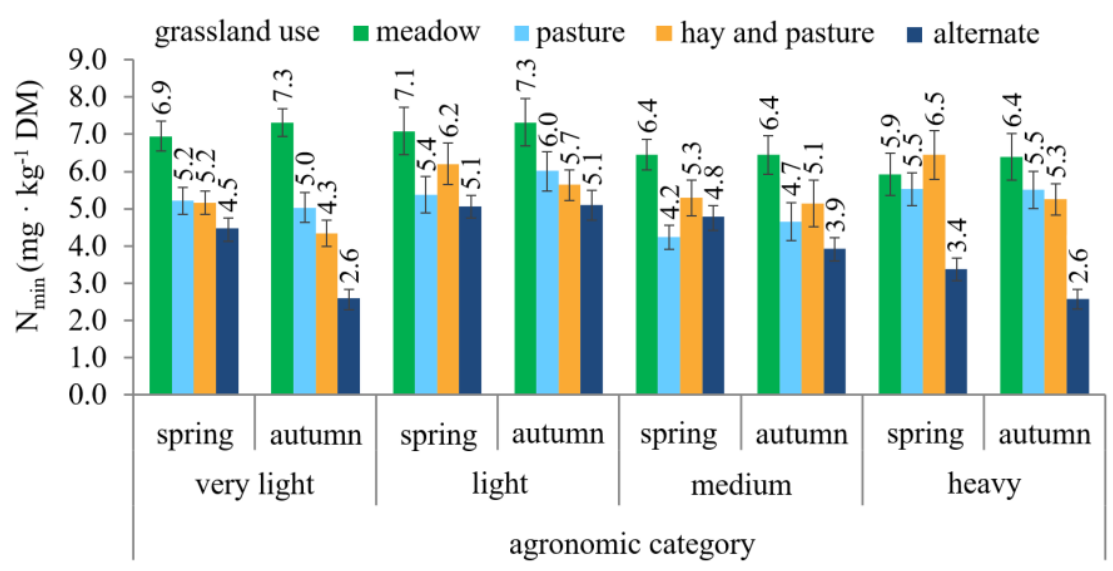

Figure 5. Average mineral nitrogen $N_{\min }$ content in the $60-90 \mathrm{~cm}$ layer of grassland soils with its standard deviation depending on grassland land use, sampling date and agronomic category. DM stands for dry matter of the soil sample 
Observed relationships between soil agronomic category and mineral nitrogen content in the $60-90 \mathrm{~cm}$ soil layer (below the main root mass of the crops under investigation) were statistically confirmed (Table 3). Regardless of sampling date and land use, soil agronomic category had a significant effect on $\mathrm{N}_{\min }$ content $(\mathrm{R}=-0.68)$, but this relationship was weaker in spring $(R=-0.42)$ and stronger in autumn $(R=-$ 0.86). It means that the $\mathrm{N}_{\min }$ losses decreased with the increase of percentage of fine particles with dimensions below $0.02 \mathrm{~mm}$ in soil, which is probably connected with lower permeability of heavier soils and therefore - reduced leaching. The dependence of $\mathrm{N}$ content on clay fraction (and, therefore, on agronomic category) was observed for USA, Australian rainforest, Denmark and the Netherlands, but those relations are not universal, however (Homann et al., 2007). According to Sapek and Kalińska (2004) the release of mineral forms during and after the growing season is increased due to the more intensive mineralization of nitrogen in the early summer months (May to July), which results in increased leaching in autumn and more pronouced relationships. The highest negative correlation was obtained for the relationship between the percentage of fine particles with dimensions below $0.02 \mathrm{~mm}$ and $\mathrm{N}_{\min }$ content for meadows $(\mathrm{R}=-$ 0.94). In turn, a positive relationship was demonstrated for hay and pasture use. A negative correlation was also obtained for alternate grasslands, but for autumn sampling date this correlation was statistically insignificant. As far as the field crop plants in question are concerned, a positive relationship between $N_{\min }$ content in the $60-90 \mathrm{~cm}$ layer and soil agronomic category was confirmed for maize crops. Opposite relationships were revealed for mixed cereal crops for both sampling dates and though for spring sampling these relationships are insignificant from the statistical point of view, a high and statistically significant correlation coefficient in the case of the autumn sampling date was obtained.

Table 3. Correlation coefficients between soil agronomic categories and mineral nitrogen $N_{\min }$ content in the $60-90 \mathrm{~cm}$ soil layer with a breakdown into both land use and sampling date

\begin{tabular}{c|c|c}
\hline \multirow{2}{*}{ Land use } & \multicolumn{2}{c}{ Sampling date } \\
\cline { 2 - 3 } & spring & autumn \\
\hline Grasslands (on mineral soils) & $-0.96^{*}$ & $-0.95^{*}$ \\
Meadows (on mineral soils) & $-0.94^{*}$ & $-0.92^{*}$ \\
Pastures (on mineral soils) & -0.02 & -0.02 \\
Hay and pasture grasslands (on mineral soils) & $0.57^{*}$ & $0.45^{*}$ \\
Alternate grasslands (on mineral soils) & $-0.69^{*}$ & -0.22 \\
Maize & $0.84^{*}$ & $0.89^{*}$ \\
Mixed cereals & -0.40 & $-0.98^{*}$ \\
\hline Total soils & $-0.42^{*}$ & $-0.86^{*}$ \\
\hline Total soils (on an annual basis) & \multicolumn{2}{|c}{$-0.68^{*}$} \\
\hline
\end{tabular}

${ }^{*}$ correlation significant at significance level $\mathrm{p}=0.05$

After confirming that the relationship between soil agronomic category and content of mineral nitrogen in $60-90 \mathrm{~cm}$ soil layer exists, equations describing those relations were elaborated (Figs 6-8). The determined linear regression equations can be of great importance from the practical point of view, as they may be used to forecast changes in mineral nitrogen content depending on the percentage of fine particles in mineral soil. Therefore they may help the farmer to identify the optimal dose of mineral nitrogen in soils with different agronomic category and suppress nitrogen losses and thus adverse 
impact on the environment. Significance of relationships described by obtained equations was confirmed by the high coefficients of determination.
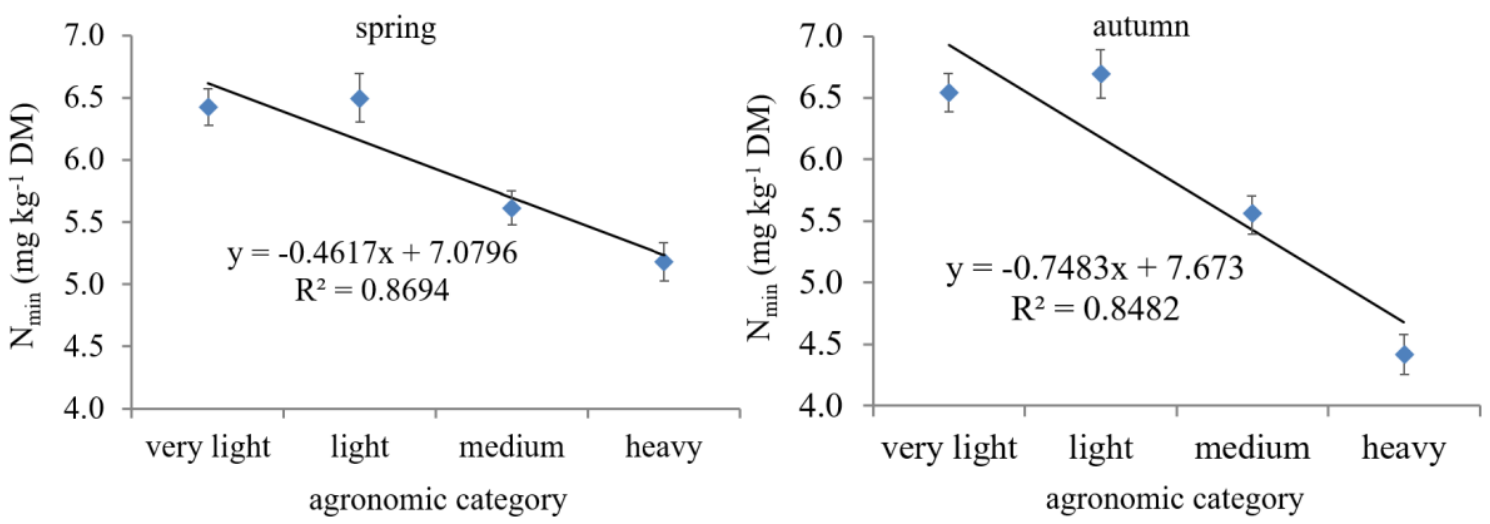

Figure 6. Relationship between agronomic category and average mineral nitrogen $N_{\text {min }}$ content in the 60-90 cm layer of mineral soils under grasslands with its standard deviation for spring and autumn soil sampling dates. DM stands for dry matter of the soil sample
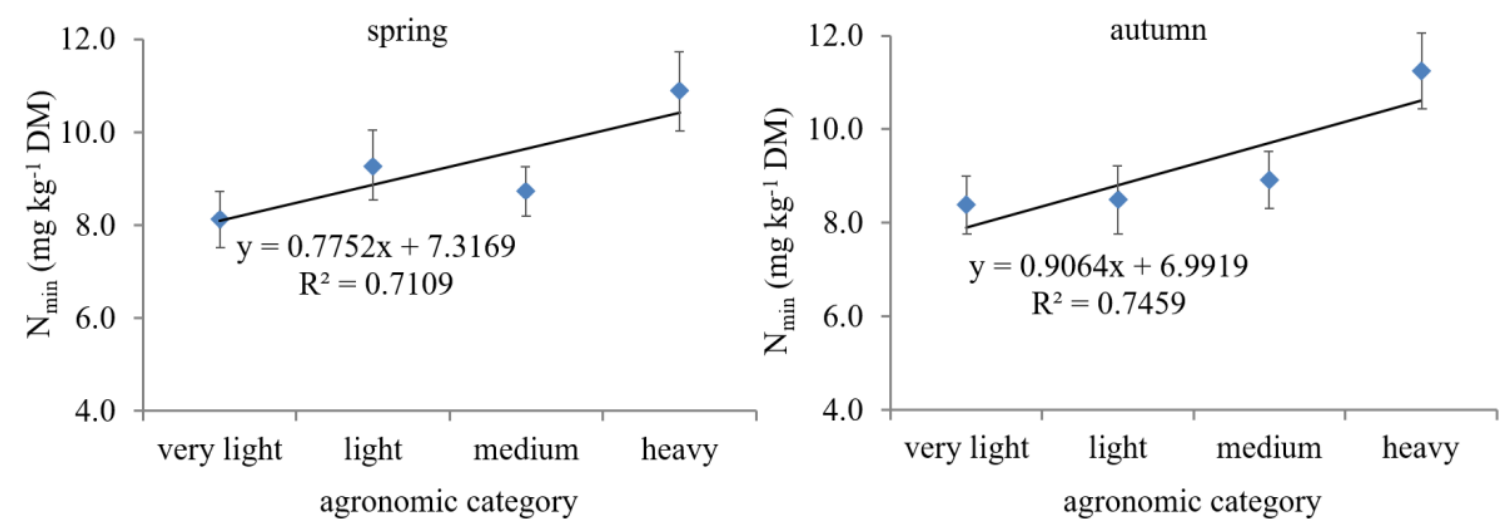

Figure 7. Relationship between agronomic category and average mineral nitrogen $N_{\text {min }}$ content in the 60-90 cm layer of of mineral soils under maize with its standard deviation for spring and autumn soil sampling dates. DM stands for dry matter of the soil sample
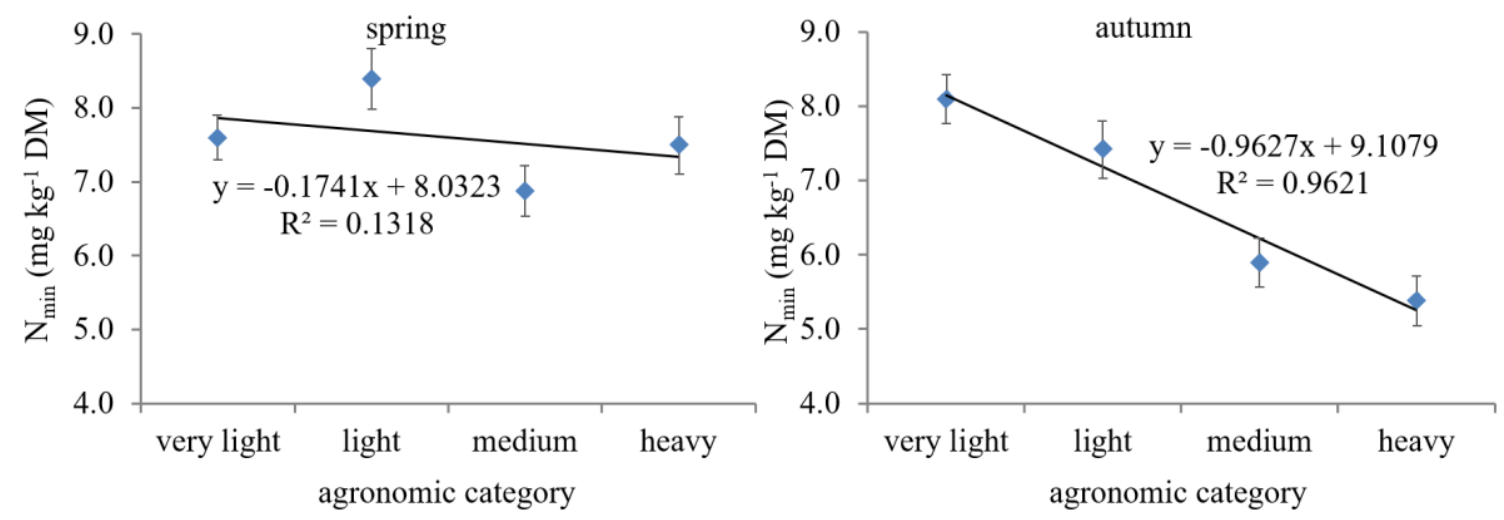

Figure 8. Relationship between agronomic category and average mineral nitrogen $N_{\min }$ content in the 60-90 cm layer of mineral soils under mixed cereals with its standard deviation for spring and autumn soil sampling dates. DM stands for dry matter of the soil sample 


\section{Conclusions}

The results of this study confirm that significant differences in the content of mineral nitrogen can be observed in the soil layer beneath $60 \mathrm{~cm}$, which is beyond the reach of the main root mass of crop plants in grassland soils and in arable soils, depending on agronomic categories and sampling date. It speaks for the fact that the leeching into deeper layers of soil occurs, which can have significant environmental consequences. Therefore, fertilization doses should take into account agronomic soil categories and type of land use. Regardless of observation period and the percentage of fine particles in mineral soils, the lowest content of $\mathrm{N}_{\min }$ was shown in grassland soils, whereas greater accumulation of this nutrient in the soil profile at a depth of $60-90 \mathrm{~cm}$ was observed in the soils under both maize and mixed cereals. This was especially evident for soils under maize. It was revealed that agronomic category and the content of $\mathrm{N}_{\min }$ in the 60$90 \mathrm{~cm}$ soil layer, regardless of the land use or sampling date, are strongly correlated. Elaborated equations describing those relationships for different land uses and sampling dates are characterized by very high coefficients of determination $\mathrm{R}^{2}$, which suggest that they may be successfully used in precision agriculture and contribute to sustainable management of fertilizers usage leading to reduction of nitrogen leaching from topsoil to groundwater, thus decreasing the negative impact of agricultural land use on environment.

Acknowledgements. This paper has been partly financed from the funds of the Polish National Centre for Research and Development in frame of the project BIO-FERTIL, contract number: BIOSTRATEG3/347464/5/NCBR/2017.

\section{REFERENCES}

[1] Arbačiauskas, J., Staugaitis, G., Vaišvila, Z., Mažvila, J., Adomaitis, T., Šumskis, D., Enė, L. Ž., Lubytė, J., Mažeika, R. (2014): The interdependence of mineral nitrogen content in different soil layers of Lithuanian agricultural lands. - Žemdirbystė (Agriculture) 101(2): 133-138. http://dx.doi.org/10.13080/z-a.2014.101.017.

[2] Baranowski, P., Krzyszczak, J., Sławiński, C., Hoffmann, H., Kozyra, J., Nieróbca, A., Siwek, K., Gluza, A. (2015): Multifractal analysis of meteorological time series to assess climate impacts. - Climate Research 65: 39-52. https://doi.org/10.3354/cr01321.

[3] Bonin, C., Flores, J., Lal, R., Tracy, B. (2013): Root Characteristics of Perennial WarmSeason Grasslands Managed for Grazing and Biomass Production. - Agronomy 3: 508523. https://doi.org/10.3390/agronomy3030508.

[4] Coyne, M. S., Frye, W. W. (2005): Nitrogen in soil. Cycle. - In: Hillel, D. (ed.) Encyclopedia of soil in the environment. Elsevier Ltd., 13-21.

[5] De Notaris, C., Rasmussen, J., Sørensen, P., Olesen, J.E. (2017): Nitrogen leaching: a crop rotation perspective on the effect of $\mathrm{N}$ surplus, field management and use of catch crops. - Agriculture, Ecosystems and Environment 255: 1-11. https://doi.org/10.1016/j.agee.2017.12.009

[6] Fan, J., McConkey, B., Wang, H., Janzen, H. (2016): Root distribution by depth for temperate agricultural crops. - Field Crops Research 189: 68-74. https://doi.org/10.1016/j.fcr.2016.02.013.

[7] Fotyma, E., Pietruch, Cz. (2000): Monitoring of the mineral nitrogen content in soils of arable land of Poland - the possibilities of practical use. - Biuletyn Informacyjny IUNG 12: 18-25. (in Polish) 
[8] Fotyma, M., Kęsik, K., Pietruch, C. (2010): Mineral nitrogen in soils of Poland as an indicator of plants nutrient requirements and soil water cleanness. - Fertilizers and Fertilization 38: 4-83. (in Polish).

[9] Fronzek, S., Pirttioja, N., Carter, T. R., Bindi, M., Hoffmann, H., Palosuo, T., RuizRamos, M., Tao, F., Trnka, M., Acutis, M., Asseng, S., Baranowski, P., Basso, B., Bodin, P., Buis, S., Cammarano, D., Deligios, P., Destain, M. F., Dumont, B., Ewert, F., Ferrise, R., François, L., Gaiser, T., Hlavinka, P., Jacquemin, I., Kersebaum, K. C., Kollas, C., Krzyszczak, J., Lorite, I. J., Minet, J., Minguez, M. I., Montesino, M., Moriondo, M., Müller, C., Nendel, C., Öztürk, I., Perego, A., Rodríguez, A., Ruane, A. C., Ruget, F., Sanna, M., Semenov, M. A., Sławiński, C., Stratonovitch, P., Supit, I., Waha, K., Wang, E., Wu, L., Zhao, Z., Rötter, R. P. (2018): Classifying multi-model wheat yield impact response surfaces showing sensitivity to temperature and precipitation change. Agricultural Systems 159: 209-224. https://doi.org/10.1016/j.agsy.2017.08.004.

[10] García-Díaz, A., Bienes, R., Sastre, B., Novara, A., Gristina, L., Cerdà, A. (2017): Nitrogen losses in vineyards under different types of soil groundcover. A field runoff simulator approach in central Spain. - Agriculture, Ecosystems \& Environment 236: 256267. https://doi.org/10.1016/j.agee.2016.12.013.

[11] Gleń-Karolczyk, K., Boligłowa, E., Antonkiewicz, J. (2018): Organic fertilization shapes the biodiversity of fungal communities associated with potato dry rot. - Applied Soil Ecology 129: 43-51. https://doi.org/10.1016/j.apsoil.2018.04.012.

[12] Hoffmann, H., Baranowski, P., Krzyszczak, J., Zubik, M., Sławiński, C., Gaiser, T., Ewert, F. (2017): Temporal properties of spatially aggregated meteorological time series. - Agricultural and Forest Meteorology 234-235: 247-257. https://doi.org/10.1016/j.agrformet.2016.12.012.

[13] Homann, P.S., Kapchinske, J.S. Boyce, A. (2007): Relations of mineral-soil C and N to climate and texture: regional differences within the conterminous USA. Biogeochemistry 85: 303. https://doi.org/10.1007/s10533-007-9139-6

[14] IUNG (1990): Fertilizer recommendations I: Limiting values to assess macro- and microelement contents in soils. - Instytut Uprawy Nawożenia i Gleboznawstwa P(44): 26. (in Polish)

[15] Jadczyszyn, T., Pietruch, Cz., Lipiński, W. (2010): Soil monitoring in Poland for the content of mineral nitrogen in the years 2007-2009. - Fertilizers and Fertilization 38: 84110. (in Polish)

[16] Jarosiewicz, A., Tomaszewska, M. (2003): Controlled-release NPK fertilizer encapsulated by polymeric membranes. - Journal of Agricultural and Food Chemistry 51: 413-417.

[17] Krzyszczak, J., Baranowski, P., Hoffmann, H., Zubik, M., Sławiński, C. (2017a): Analysis of Climate Dynamics Across a European Transect Using a Multifractal Method. - In: Rojas, I., Pomares, H., Valenzuela, O. (eds.) Advances in Time Series Analysis and Forecasting: Selected Contributions from ITISE 2016. Contributions to Statistics. Springer International Publishing, Cham, 103-116. https://doi.org/10.1007/978-3-31955789-2_8.

[18] Krzyszczak, J., Baranowski, P., Zubik, M., Hoffmann, H. (2017b): Temporal scale influence on multifractal properties of agro-meteorological time series. - Agricultural and Forest Meteorology 239: 223-235. https://doi.org/10.1016/j.agrformet.2017.03.015.

[19] Krzyszczak, J., Baranowski, P., Zubik, M., Kazandjiev, V., Georgieva, V., Sławiński, C., Siwek, K., Kozyra, J., Nieróbca, A. (2018): Multifractal characterization and comparison of meteorological time series from two climatic zones. - Theoretical and Applied Climatology (in press). http://dx.doi.org/10.1007/s00704-018-2705-0.

[20] Lamorski, K., Pastuszka, T., Krzyszczak, J., Sławiński, C., Witkowska-Walczak, B. (2013): Soil water dynamic modeling using the physical and support vector machine methods. - Vadose Zone Journal 12(4). https://doi.org/10.2136/vzj2013.05.0085. 
[21] Łoginow, W., Janowiak, J., Spychaj-Fabisiak, E. (1987): The variability of the total content of the individual forms of nitrogen in the soil. - Zeszyty Naukowe ATR Bydgoszcz 23: 13-24. (in Polish).

[22] Mezhunts, B., Britt, C., McMillan, S., Givens D. (2005): The distribution of root biomass and energy yields in mountain grasslands in Armenia. - Electronic Journal of Natural Sciences of the NAS of Armenia, Ecology 1: 1-5.

[23] Mosier, A.R., Doran, J.W., Freney, J.R. (2002): Managing soil denitrification. - Journal of Soil and Water Conservation 57(6): 505-513

[24] Murat, M., Malinowska, I., Gos, M., Krzyszczak, J. (2018): Forecasting daily meteorological time series using ARIMA and regression models. - International Agrophysics 32(2): 253-264. https://doi.org/10.1515/intag-2017-0007.

[25] Pawluczuk, J., Gotkiewicz, J. (2003): Evaluation of the mineralization process in soils of selected peat ecosystems of North-Eastern Poland in an aspect of soil resources protection. - Acta Agrophysica 1(4): 721-728. (in Polish)

[26] Pawluczuk, J., Szymczyk, S. (2008): Dynamics of organic nitrogen mineralisation in muck soils of Dymerskie Meadows and the content of nitrate and ammonium nitrogen in groundwaters. - Water-Environment-Rural Areas 8, 2b(24): 105-115. (in Polish)

[27] Paz, J. M., Ramos, C. (2004): Simulation of nitrate leaching for different nitrogen fertilization rates in a region of Valencia (Spain) using a GIS-GLEAMS system. Agriculture, Ecosystems \& Environment 103: 59-73.

[28] Pietrzak, S. (2014): The amount of inorganic nitrogen in mineral meadow soils in Poland in the years 2008-2012. - Water-Environment-Rural Areas 14, 3(47): 113-124. (in Polish)

[29] Pirttioja, N., Carter, T. R., Fronzek, S., Bindi, M., Hoffmann, H., Palosuo, T., RuizRamos, M., Tao, F., Trnka, M., Acutis, M., Asseng, S., Baranowski, P., Basso, B., Bodin, P., Buis, S., Cammarano, D., Deligios P., Destain, M. F., Dumont, B., Ewert, F., Ferrise, R., François, L., Gaiser, T., Hlavinka, P., Jacquemin, I., Kersebaum, K. C., Kollas, C., Krzyszczak, J., Lorite, I. J., Minet, J., Minguez, M. I., Montesino, M., Moriondo, M., Müller, C., Nendel, C., Öztürk, I., Perego, A., Rodríguez, A., Ruane, A. C., Ruget, F., Sanna, M., Semenov, M. A., Sławiński, C., Stratonovitch, P., Supit, I., Waha, K., Wang, E., Wu, L., Zhao, Z., Rötter, R. P. (2015): Temperature and precipitation effects on wheat yield across a European transect: a crop model ensemble analysis using impact response surfaces. - Climate Research 65: 87-105. https://doi.org/10.3354/cr01322.

[30] Powlson, D. S. (1988): Measuring and minimising losses of fertilizer nitrogen in arable agriculture. - In: Jenkinson, D. S., Smith, K. A. (eds.) Nitrogen Efficiency in Agricultural Soils. Elsevier Applied Science, 231-245.

[31] Regulation (2002): Regulation of the Minister of Environment concerning the criteria for designation of waters vulnerable to pollution by nitrogen compounds from agricultural sources. - Dziennik Ustaw (Journal of Laws) of 2002, No. 241, item 2093. (in Polish)

[32] Rodríguez, A., Ruiz-Ramos, M., Palosuo, T., Carter, T. R., Fronzek, S., Lorite, I. J., Ferrise, R., Pirttioja, N., Bindi, M., Baranowski, P., Buis, S., Cammarano, D., Chen, Y., Dumont, B., Ewert, F., Gaiser, T., Hlavinka, P., Hoffmann, H., Höhn, J. G., Jurecka, F., Kersebaum, K. C., Krzyszczak, J., Lana, M., Mechiche-Alami, A., Minet, J., Montesino, M., Nendel, C., Porter, J. R., Ruget, F., Semenov, M. A., Steinmetz, Z., Stratonovitch, P., Supit, I., Tao, F., Trnka, M., de Wit, A., Rötter, R. P. (2019): Implications of crop model ensemble size and composition for estimates of adaptation effects and agreement of recommendations. - Agricultural and Forest Meteorology 264: 351-362. https://doi.org/10.1016/j.agrformet.2018.09.018.

[33] Ruiz-Ramos, M., Ferrise, R., Rodríguez, A., Lorite, I. J., Bindi, M., Carter, T. R., Fronzek, S., Palosuo, T., Pirttioja, N., Baranowski, P., Buis, S., Cammarano, D., Chen, Y., Dumont, B., Ewert, F., Gaiser, T., Hlavinka, P., Hoffmann, H., Höhn, J. G., Jurecka, F., Kersebaum, K. C., Krzyszczak, J., Lana, M., Mechiche-Alami, A., Minet, J., Montesino, M., Nendel, C., Porter, J. R., Ruget, F., Semenov, M. A., Steinmetz, Z., 
Stratonovitch, P., Supit, I., Tao, F., Trnka, M., de Wit, A., Rötter, R. P. (2018): Adaptation response surfaces for managing wheat under perturbed climate and $\mathrm{CO}_{2}$ in a Mediterranean environment. - Agricultural Systems 159: 260-274. https://doi.org/10.1016/j.agsy.2017.01.009.

[34] Sapek, B., Kalińska, D. (2004): Mineralization of soil organic nitrogen compounds in the light of long-term grassland experiments in IMUZ. - Water-Environment-Rural Areas 4, 1(10): 183-200. (in Polish).

[35] Soon, Y. K., Clayton, G. W., Rice, W. A. (2001): Tillage and previous crop effects on dynamics of nitrogen in a wheat-soil system. - Agronomy Journal 93: 842-849.

[36] Statistical Yearbook of the Republic of Poland (2011). Central Statistical Office. Department of Statistical Publishing GUS, Warsaw.

[37] Statistical Yearbook of the Republic of Poland (2012). Central Statistical Office. Department of Statistical Publishing GUS, Warsaw.

[38] Statistical Yearbook of the Republic of Poland (2013). Central Statistical Office. Department of Statistical Publishing GUS, Warsaw.

[39] Swanson, K. L., Tsonis A. A. (2009): Has the climate recently shifted? - Geophysical Research Letters 36: L06711. https://doi.org/10.1029/2008GL037022.

[40] The World Bank (2015): World Development Indicators. Arable land (\% of land area) [Data file]. - Food and Agriculture Organization, electronic files and web site. Retrieved from https://data.worldbank.org/indicator/AG.LND.ARBL.ZS?locations=PL.

[41] Tkaczyk, P., Bednarek, W., Dresler, S., Krzyszczak, J., Baranowski, P., Sławiński, C. (2017): Relationship between assimilable-nutrient content and physicochemical properties of topsoil. - International Agrophysics 31(4): 551-562. https://doi.org/10.1515/intag-2016-0074.

[42] Tkaczyk, P., Bednarek, W., Dresler, S., Krzyszczak, J. (2018a): The effect of some soil physicochemical properties and nitrogen fertilisation on winter wheat yield. - Acta Agrophysica 25(1): 107-116. https://doi.org/10.31545/aagr0009.

[43] Tkaczyk, P., Bednarek, W., Dresler, S., Krzyszczak, J., Baranowski, P., Brodowska, M. S. (2018b): Content of certain macro and microelements in orchard soils in relation to agronomic categories and reaction of these soils. - Journal of Elementology 23(4): 13611372. https://doi.org/10.5601/jelem.2018.23.1.1639.

[44] Tunbare, R., Benike, I., Tralmaka, L. (2005): The content of nitrate in soil and water in Latvia as a base for sustainable nitrogen management. - Fertilizers and Fertilization 1(22): 136-151.

[45] Walkiewicz, A., Bulak, P., Brzezińska, M., Wnuk, E., Bieganowski, A. (2016): Methane oxidation in heavy metal contaminated Mollic Gleysol under oxic and hypoxic $\begin{array}{llll}\text { conditions. } & - & \text { Environmental } & \text { Pollution 213: 403-411. }\end{array}$ https://doi.org/10.1016/j.envpol.2016.02.048.

[46] Walkiewicz, A., Brzezińska, M., Bieganowski, A. (2018): Methanotrophs are favored under hypoxia in ammonium-fertilized soils. - Biology and Fertility of Soils 54(7): 861870. https://doi.org/10.1007/s00374-018-1302-9.

[47] Watros, A., Lipińska, H., Lipiński, W., Tkaczyk, P., Krzyszczak, J., Baranowski, P. (2018): The impact of fertilization on the mineral nitrogen content in grassland and fodder crop soils. - Przemysł Chemiczny 97(11): 1899-1905. https://doi.org/ 10.15199/62.2018.11.17. (in Polish).

[48] Wnuk, E., Walkiewicz, A., Bieganowski, A. (2017): Methane oxidation in leadcontaminated mineral soils under different moisture levels. - Environmental Science and Pollution Research 24(8-9): 1-9. https://doi.org/10.1007/s11356-017-0195-8.

[49] Yu, Z., Kraus, T. E. C., Dahlgren, R. A., Horwath, W. R., Zasoski, R. J. (2003): Mineral and dissolved organic nitrogen dynamics along a soil acidity-fertility gradient. - Soil Science Society of America Journal 67: 878-888. 